\title{
Biostratigraphic correlation, paleoenvironment stress, and subrosion pipe collapse: Dutch Rhaetian shales uncover their secrets
}

\author{
Adiël A. Klompmaker • G. F. Waldemar Herngreen • \\ Henk W. Oosterink
}

Received: 24 January 2010 / Accepted: 1 August 2010 / Published online: 19 August 2010

(C) The Author(s) 2010. This article is published with open access at Springerlink.com

\begin{abstract}
A subrosion pipe or sinkhole is a geologic phenomenon that occurs due to dissolution of strata in the subsurface causing the overlying sediments to collapse. The subrosion pipe in the Winterswijk quarry complex in the eastern Netherlands yielded rare, dark-colored shales. Bivalves and palynomorphs indicate that the shales were deposited during the Rhaetian (uppermost Triassic). In addition, detailed correlation with other NW European localities in Great Britain, Austria, and Germany further constrained the age of the shales to the middle of the Rhaetian. The shales were deposited in a near-coastal environment and contained a low diverse macroinvertebrate fauna with bivalves and some brittle stars that lived in a hostile environment, probably caused by low salinity and oxygen levels. These middle Rhaetian shales were mixed with dark-colored middle to late Hettangian sediments, both overlying Middle Triassic (Anisian) strata, which is present in the pipe as well. The presence of Rhaetian sediments in the subrosion pipe reopened the discussion on its age of formation. We suggest that a collapse in the Middle Eocene is most likely. This research expands the knowledge of the
\end{abstract}

A. A. Klompmaker $(\bowtie)$

Department of Geology, Kent State University,

221 McGilvrey Hall, Kent, OH 44242, USA

e-mail: adielklompmaker@gmail.com

\section{A. A. Klompmaker}

Morelissenstraat 9, 8095 PX 't Loo, Oldebroek, The Netherlands

G. F. Waldemar Herngreen

Laboratory of Palaeobotany and Palynology, Utrecht University, Budapestlaan 4, 3584 CD Utrecht, The Netherlands

H. W. Oosterink

Hortensialaan 64, 7101 XH Winterswijk, The Netherlands marine realms in the uppermost Triassic in Europe, just prior to the Permian-Triassic extinction event.

Keywords Biostratigraphy · Bivalves · The Netherlands · Paleoecology $\cdot$ Palynomorphs $\cdot$ Triassic

\section{Introduction}

Rhaetian sediments have been found in many NW European countries including Great Britain, Austria, Germany and the Netherlands. Dutch Rhaetian sediments are scarce in the subsurface and even rarer at the outcrop. 'Landmark 94' (Herngreen and De Boer 1974) is an outcrop close to the German border. The only other two outcrops have been found in the Winterswijk quarry complex in a subrosion pipe in Quarry III and in the northernmost part of Quarry IV (Figs. 1, 2). Dutch Rhaetian sediments are assigned to the Sleen Formation, the lowermost unit of the Altena Group (Van Adrichem-Boogaert and Kouwe 1993-1997). Past research on these shales at Winterswijk is limited. Herngreen et al. (2000b, 2005a, b) primarily reported on the palynomorphs of the shale at Quarry IV. Lissenberg (1989) proposed a preliminary Hettangian/Sinemurian age for the shales in the subrosion pipe (Quarry III) based on micropaleontological evidence (ostracods, foraminifers, and holothurians), while Herngreen (1989) suggested a late Hettangian age as based on sporomorphs. Herngreen et al. (2005a, b) mentioned the occurrence of the subrosion pipe. Oosterink et al. $(2005,2006)$ first described the pipe and referred to the shale as Rhaetian/Lower Jurassic based on the references mentioned above and rather ambiguous red spots which would be indicative of the Rhaetian (Gerth 1955). Subsequently, Klompmaker and Van den Berkmortel (2007) reported on middle to late Hettangian ammonites 


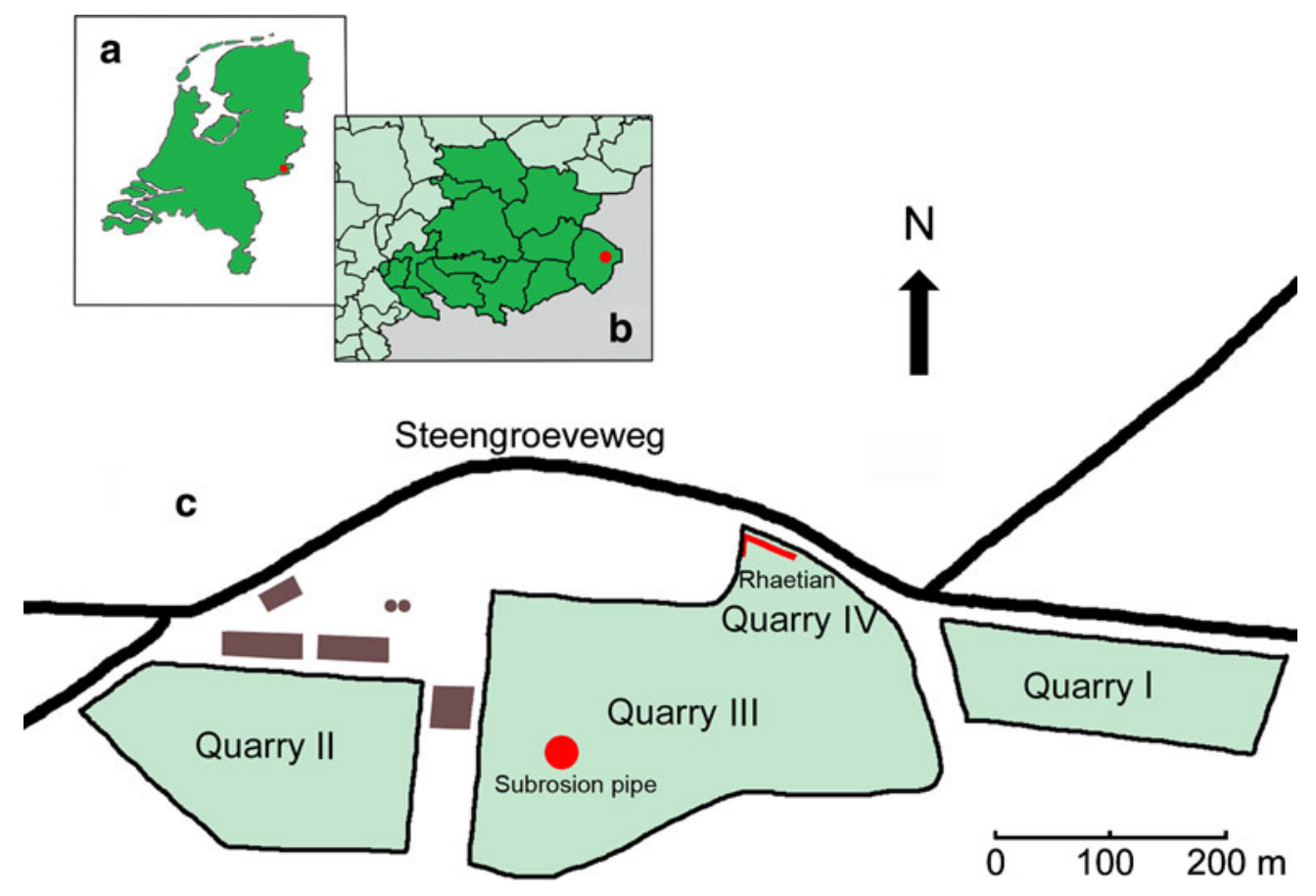

Fig. 1 The location of the studied sediments; $\mathbf{a}$ in the eastern Netherlands, $\mathbf{b}$ in the Achterhoek area, and $\mathbf{c}$ an overview of the Winterswijk quarry complex east of the city of Winterswijk (modified after Klompmaker and Van den Berkmortel 2007: Fig. 1)

that were intermixed with the shales. They noted that part of the shale might be Rhaetian in age based on the presence of disarticulated fish remains, bivalves, and possible parts of a pyrite layer in the subrosion pipe and in the Rhaetian shales of Quarry IV. Thuy et al. (2008) recorded Rhaetian brittle stars from shales of the pipe. The Rhaetian sediments from the pipe have been removed and only a few samples could be saved for this study.

The term subrosion refers to subsurface erosion due to the solution of salt(s) and/or gypsum/anhydrite followed by subsequent adjustment and/or collapse of overlying strata resulting in a so-called subrosion pipe or sinkhole. This happens today in the areas bordering the Dead Sea in Israel (Fig. 3), which is drying up. The subrosion pipe at the Winterswijk quarry complex (Fig. 1) could be caused by dissolution of evaporite deposits of the Zechstein or Röt. Oosterink et al. (2006) suggested that dissolution of the latter and subsequent collapse of the overlying strata most likely caused the subrosion pipe to form. Collapse of strata due to dissolution of salts in the underlying Zechstein Group (Permian), the top of which is at much greater depths between 500 and $800 \mathrm{~m}$ east of Winterswijk, was considered to be less plausible. Oosterink et al. (2006) hypothesized that the pipe formed well after the Oligocene, but prior to the Quaternary.

The purpose of this study is to investigate the Rhaetian strata from the subrosion pipe in detail, to describe the stratigraphy from the subrosion pipe, and to readdress its age of formation. In addition, the presence of (micro)fossils found within the Rhaetian shales provides the opportunity to determine the precise age by means of correlation to other NW European localities. These fossils also allow a reconstruction of the paleoenvironment in which the shales were deposited. This study significantly contributes to the knowledge of the marine Rhaetian in NW Europe on the brink of the Permian-Triassic extinction event.

\section{Regional geology}

The following compilation of the regional geology of the Netherlands is based on papers by Herngreen and Wong $(2007,2008)$ and in more detail for the Achterhoek area in the eastern Netherlands based on NITG-TNO (1998) and Herngreen et al. (2000b).

During the Late Permian and Jurassic, the structural outline of the Netherlands progressively changed from one single, extensive basin into a pattern of smaller, fault-bounded basins and highs. The remarkable differences in sedimentary development of the various basins around the Jurassic/ Cretaceous boundary can be understood in the context of tectonic events in the Northwest European Basin. This change is associated with the disintegration of Pangea (Ziegler 1990). It occurred in extensional phases of which the Early Kimmerian Phase (Late Triassic), the Middle Kimmerian Phase (Middle Jurassic) and the Late Kimmerian Phase (Kimmeridgian-Valanginian) are important for 

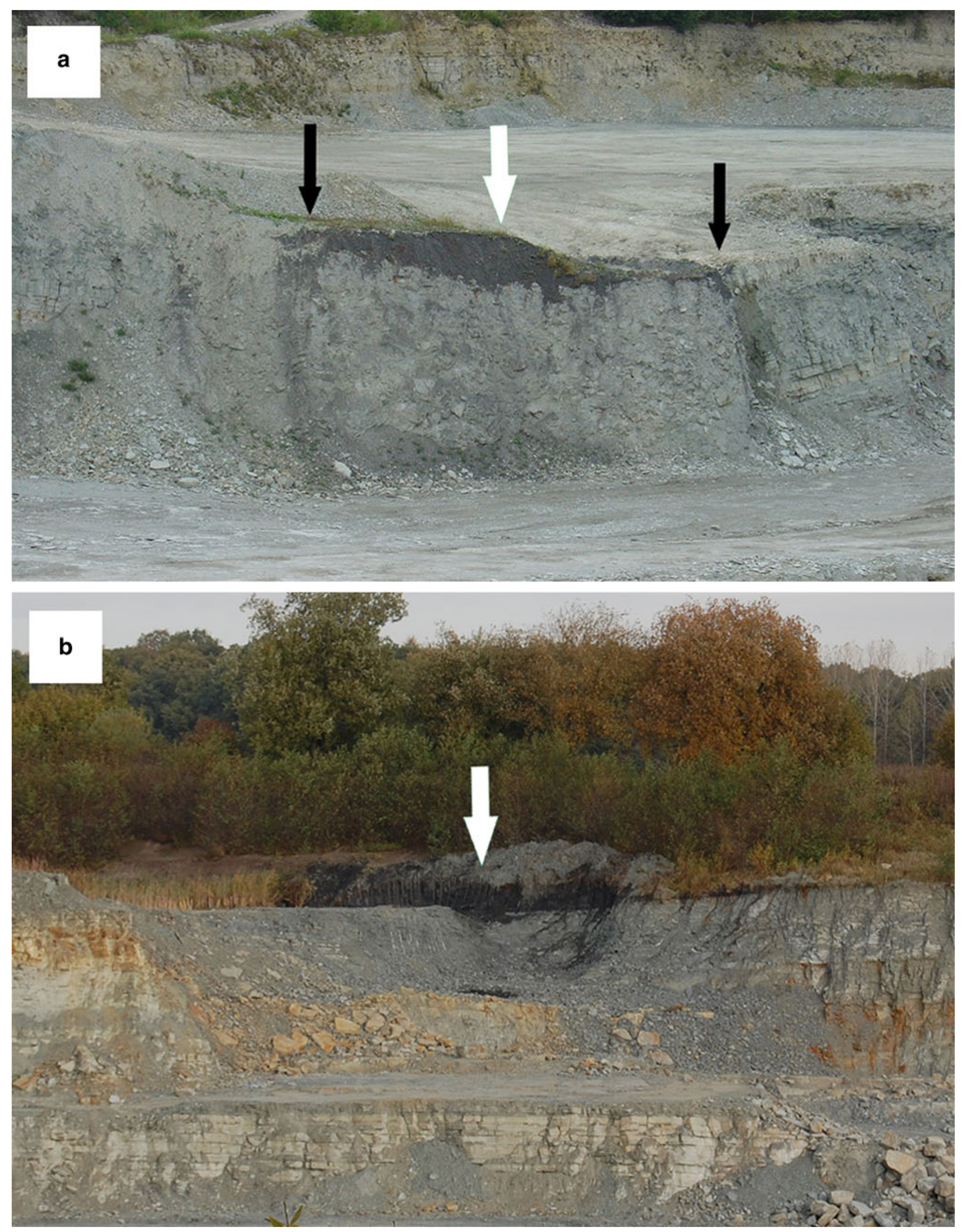

Fig. 2 The two localities within the Winterswijk quarry complex exhibiting dark-colored shales (white arrows). a Subrosion pipe at Quarry III in 2004 (in between the black arrows). b Rhaetian sediments at Quarry IV in 2008 (a from Oosterink et al. 2006) 
the present study. Rift structures such as the Central Netherlands Basin and Lower Saxony Basin originated during this period or constitute rejuvenated Paleozoic elements. In the Early Cretaceous, thermal subsidence became important, and transgression gradually took place. This flooding was briefly interrupted by the Early Albian Austrian tectonic phase and followed by the widely recognized Albian transgression. During Late Cretaceous times, the influx of clastics decreased due to the submergence of nearby source areas, and calcareous sedimentation increased. The Subhercynian (Santonian-Campanian) and Laramide (Paleocene) tectonic phases caused strong differential subsidence and tectonic inversion of former Jurassic basins. In the Winterswijk area, the Late Permian lithostratigraphic units are assigned to the Rotliegend Group, comprising mainly sandstones and conglomerates, and the overlying Zechstein Group, which comprises several evaporite cycles with rock salt and carbonate anhydrites and sabkha-mudflat deposits. The sedimentary development of the Lower Germanic Trias Group with Bunter Sandstone and Shale and subordinate Röt rock salt formation in the lower part of the overlying Upper Germanic Trias Group is very similar to the
Permian. A distinct marine influence is present in the Muschelkalk Formation with marls, limestone, and dolomite. Younger strata of the Upper Germanic Trias Group include the claystones of the Keuper Formation. However, this formation is absent in the Winterswijk area, due to the Early Kimmerian tectonic phase followed by subsequent erosion.

The Jurassic sedimentary cycle, characterized by marine shales and sandstones, already starts with the latest Triassic Rhaetian Sleen Formation. This is the lowest formation out of the five that constitute the Altena Group and extend up into the Callovian (latest Middle Jurassic). Upper Jurassic strata are essentially unknown from the area under consideration due to the Late Kimmerian tectonic phase.

The Lower Cretaceous is incomplete with terrestrial and marginal marine sandstones and claystones of the Kuhfeld Schichten (Valanginian-Hauterivian; not assigned to a formal lithostratigraphic unit), and the fully marine Holland Formation (Aptian-Albian). Here, the last unit consists of the Holland Greensand Member (Aptian) and the Upper Holland Marl Member (Albian). This development demonstrates an increasing marine influence which continues in

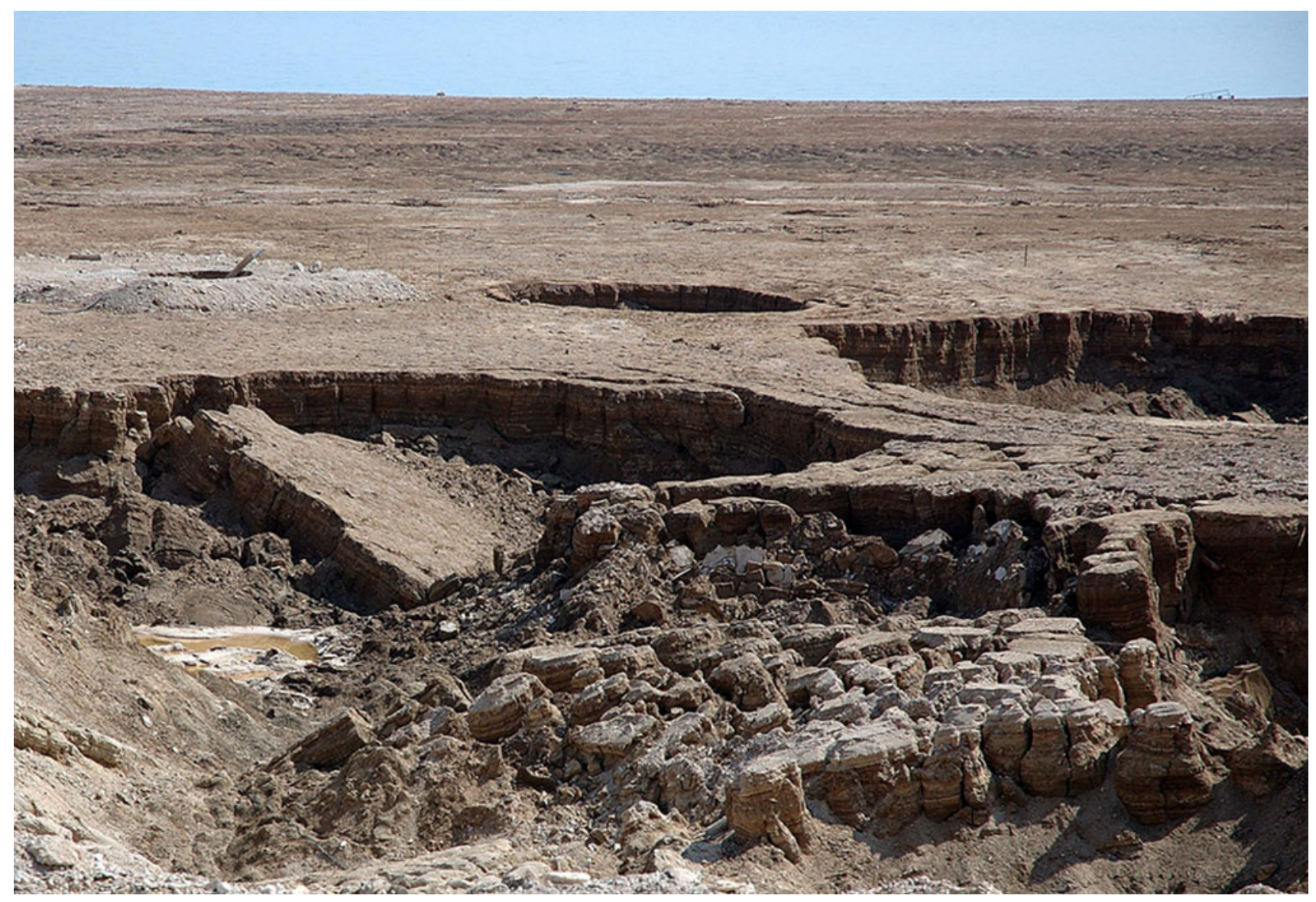

Fig. 3 Subrosion pipes close to the Dead Sea in Israel. About a thousand pipes already formed since the first was discovered about 18 years ago (photo with permission from Alfred Muller) 
the Cenomanian Texel Formation (Chalk Group) with predominantly marls. Younger Cretaceous strata, which are well developed elsewhere in the Netherlands and adjacent parts of the continental shelf in the Ommelanden Formation, have so far not been found.

The Tertiary is mainly represented by glauconitic and/or calcareous clays and fine-grained (glauconitic) sandstones of Late Paleocene, Eocene, Oligocene, and Miocene age. Hiatuses, sometimes small in scale, and slight unconformities indicate movements during the (Early) Tertiary, some of which can be attributed to the Pyrenean tectonic phase.

\section{Materials and methods}

The bivalves, palynomorphs, and sediments were used to determine the age of the shales in the subrosion pipe, and for correlation with Great Britain, Austria, and Germany. In addition, the paleoenvironment in which the shales were deposited was addressed and the age of the subrosion pipe was discussed.

\section{Bivalves}

More than 7,700 bivalves were collected from the shales of the lowermost decimeters of the subrosion pipe in 2006 and 2007 (not from the already recognized lighter-colored Hettangian clays). At that time, most of the $2 \mathrm{~m}$ mentioned by Oosterink et al. $(2005,2006)$ were already removed (GFWH remembers about $4 \mathrm{~m}$ ). In addition, 689 bivalves were collected from the Rhaetian shales at Quarry IV (2007 and 2008). All bivalves with more than half of the shell preserved were counted individually. Valves were counted as one. Bivalves were identified to genus or species level, whenever possible. The bivalves are stored in the Nationaal Natuurhistorisch Museum Naturalis, Leiden, the Netherlands (RGM numbers).

Palynology

Sample processing was carried out on two samples (A and B) from the shales of the lower two decimeters from the subrosion pipe according to TNO-standard procedures for pre-Quaternary palynology (Janssen and Dammers 2008). Chemical treatment included adding cold $\mathrm{HCl} 30 \%$, twice cold $\mathrm{HF} 30-40 \%$, and again cold $\mathrm{HCl} 30 \%$. Finally, the residue was sieved with nylon sieves of 18 and $250 \mu \mathrm{m}$ to concentrate the organic material. Heavy-liquid separation, usually using a bromoform-alcohol mixture or sodium polytungstate of specific gravity 2.1, was not applied. After counting some lines of the strew slides, the remaining parts were thoroughly scanned for special taxa. The slides are stored at TNO, Utrecht, The Netherlands.

\section{Results}

Bivalves

The three dominant species, Isocyprina sp., Tutcheria cloacina, and Rhaetavicula contorta, comprise $>95 \%$ of the bivalve fauna (Figs. 4, 5; Table 1). Isocyprina sp. is the most abundant bivalve found in the Dutch Rhaetian sediments, which is the same for Great Britain (Moore 1861). Tutcheria cloacina and Pteromya sp. were articulated in more than $10 \%$ of the cases. The total number of right valves from $R$. contorta is far greater than the number of left valves. This is probably due to the fact that the right shell is more robust. A similar result has been found for this species in Great Britain (Ivimey-Cook et al. 1999). Other than the presence of Rhaetavicula contorta in shales from borehole 'Ratum' (Herngreen and De Boer 1974), Rhaetian bivalves were not known from the Netherlands.

The actual shell material was dissolved; the bivalves were primarily preserved as moulds. Some shells showed replacement (e.g., the pyrite layer replaced the carbonate shell, sometimes accompanied by cubic pyrite crystals). The pyrite might have formed due to the former presence of organic matter inside the shell (Ivimey-Cook et al. 1999).

\section{Palynology}

Table 2 gives the complete results of the palynomorphs, and Fig. 6 shows the most important palynomorphs found in the shales of the subrosion pipe. The palynodebris of both slides shows much structureless organic matter (SOM); almost all plant fragments (wood and leaves) are converted into indeterminable macerals, subordinate, approximately 10\%, maceral type P4 (Whitaker 1984) occurs of dark brown to opaque, usually blade-like components. Regularly, the sporomorphs (pollen grains and spores) are also affected and specific determination becomes difficult or even impossible. This is exemplified in the Circumpolles-formgroup (of cheirolepidacean conifer origin) which includes here in alphabetic order Circulina meyeriana, Classopollis spp., and Corollina zwolinskae.

There is a predominance, 50-60\%, of representatives of the Circumpolles-formgroup, species of which the parent plant ecology is comparable to that of elements of the Tertiary and recent mangrove forests.

\section{Age determination}

The bivalve Rhaetavicula contorta is an index species for the Rhaetian. To confirm the Rhaetian age of the subrosion pipe shales, bivalves from the shales from Quarry IV were determined to species level if possible (Table 3) because 


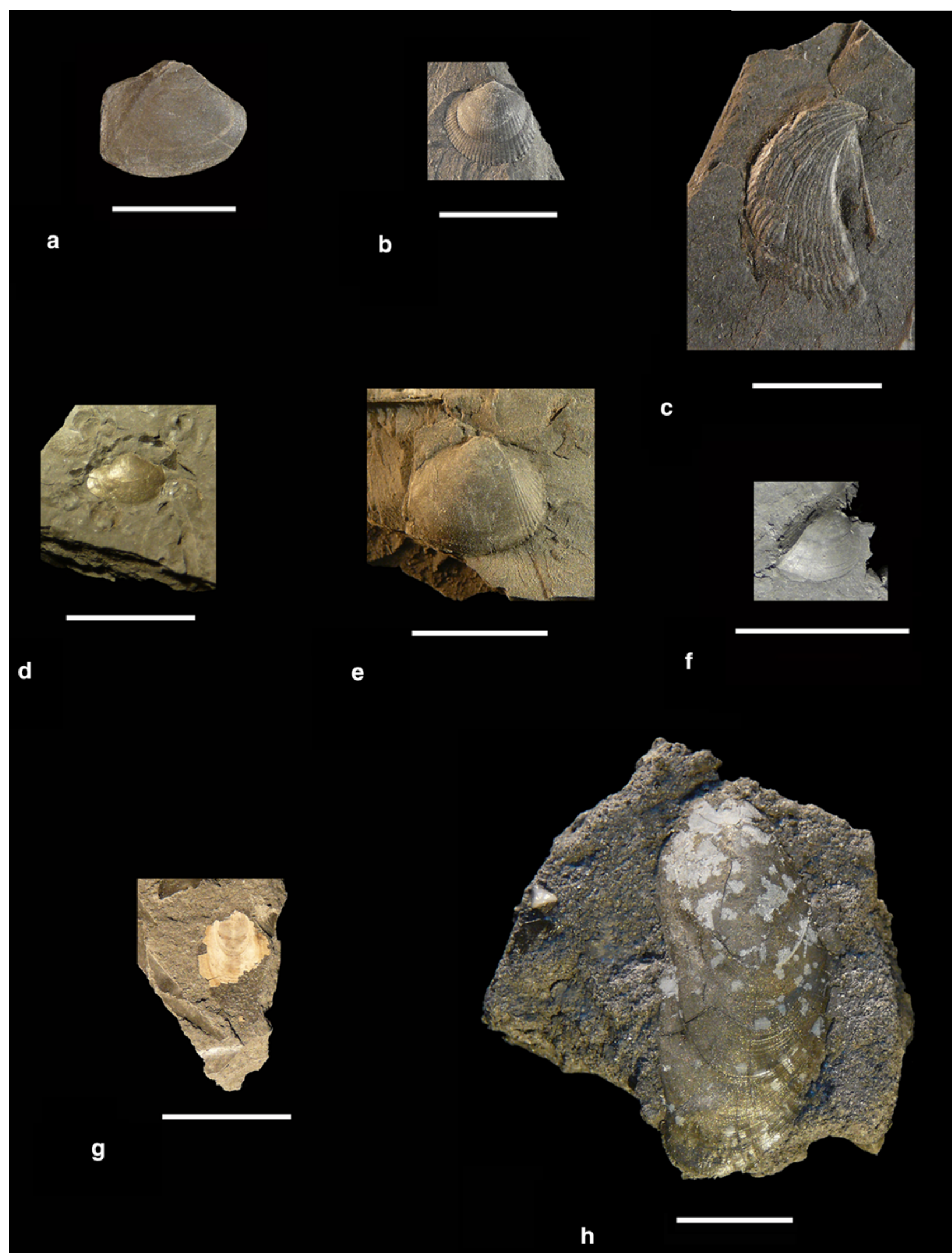


Fig. 4 Dutch Rhaetian bivalves found at Winterswijk are ordered from abundant to rare. a Isocyprina sp. (RGM 550315). b Tutcheria cloacina (RGM 550316). c Rhaetavicula contorta (RGM 550317). d Pteromya sp. (RGM 550318). e Protocardia rhaetica (RGM 550319). f Lyriomyophoria postera (RGM 550320). g Modiolus sp. (RGM 550321). h Modiolus hillanus (RGM 550322). Lyriomyophoria postera and Modiolus hillanus were found in Quarry IV, while the others were found in the subrosion pipe (Quarry III). The scale bar equals $10 \mathrm{~mm}$

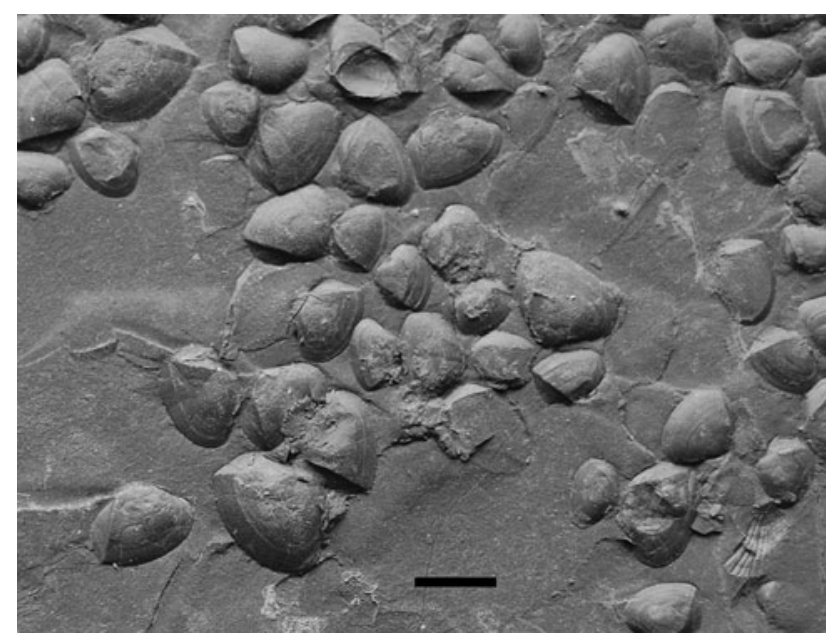

Fig. 5 Valves from most abundant bivalve, Isocyprina sp., are sometimes found together in high numbers in shales from the subrosion pipe. The scale bar equals $10 \mathrm{~mm}$

Table 1 The Rhaetian bivalves from the subrosion pipe in absolute numbers and in percentages

\begin{tabular}{lrrrr}
\hline & $\begin{array}{l}\text { Total } \\
\text { number }\end{array}$ & Percentage & Articulated & Percentage \\
\hline Isocyprina sp. & 3,906 & 50.4 & 54 & 1.4 \\
$\begin{array}{l}\text { Tutcheria cloacina } \\
\text { Rhaetavicula }\end{array}$ & 2,173 & 28.0 & 272 & 12.5 \\
$\quad 1,338$ & 17.3 & & \\
$\quad$ contorta & & & & \\
Indet. & 156 & 2.0 & & \\
$\begin{array}{l}\text { Pteromya } \text { sp. } \\
\text { Protocardia rhaetica }\end{array}$ & 57 & 1.3 & & \\
$\begin{array}{l}\text { Modiolus } \text { sp. } \\
\text { Lyriomyophoria }\end{array}$ & 11 & 0.7 & & \\
$\quad$ postera & 10 & 0.1 & & \\
cf. Isocyprina sp. & 5 & 0.1 & & \\
Total & 7,754 & 100.0 & 326 & 4.2 \\
\hline
\end{tabular}

From these, the number and percentage of articulated bivalves is given

Herngreen et al. (2005a, b) suggested a Rhaetian age for the shales of Quarry IV based on palynomorphs. All common species found in the subrosion pipe shales were found in the Quarry IV shales as well. These two arguments, one from literature and one from comparison to Quarry IV, strongly suggest that the shales from the subrosion pipe are Rhaetian in age.
Table 2 The palynomorphs in sample A and B taken from the subrosion pipe (Quarry III)

\begin{tabular}{|c|c|c|}
\hline $\begin{array}{l}\text { Palynomorphs } \\
\text { Sporomorphs }\end{array}$ & A & B \\
\hline Auritulinasporites sp. & + & \\
\hline Bisaccates, large & 3 & 4 \\
\hline Bisaccates, small & 15 & 11 \\
\hline Cerebropollenites pseudomassulae & + & 1 \\
\hline Chasmatosporites apertus & & 1 \\
\hline Chasmatosporites magnolioides & & 1 \\
\hline Circulina meyeriana & 19 & 9 \\
\hline Circumpolles indet. & 29 & 25 \\
\hline Circulina type B in Brugman 1983 & & 4 \\
\hline Classopollis spp. & 47 & 56 \\
\hline Corollina zwolinskae & 6 & 3 \\
\hline Densosporites sp. & & 1 \\
\hline Gleicheniidites & & 1 \\
\hline Granuloperculatipollis rudis & & 2 \\
\hline Heliosporites altmarkensis & + & \\
\hline Lunatisporites rhaeticus & 2 & 3 \\
\hline Ovalipollis pseudoalatus & 12 & 6 \\
\hline Peromonolites & 3 & 12 \\
\hline Quadraeculina anellaeformis & + & \\
\hline Sum of psilatriletes & 8 & 6 \\
\hline Rhaetipollis germanicus & 2 & 2 \\
\hline Ricciisporites tuberculatus & 5 & 5 \\
\hline Sporomorphs indet. & 16 & 18 \\
\hline Tasmanaceae & & + \\
\hline Todisporites sp. & + & \\
\hline Trachysporites fuscus & 2 & 1 \\
\hline cf. Uvaesporites & 1 & 3 \\
\hline Vitreisporites pallidus & 3 & 2 \\
\hline Sum of sporomorphs & 173 & 177 \\
\hline Sum of Circumpolles-complex & 101 & 97 \\
\hline \multicolumn{3}{|l|}{ Marine elements } \\
\hline Acritarchs & 2 & 1 \\
\hline Cymatiosphaera & & 2 \\
\hline Rhaetogonyaulax & 1 & 5 \\
\hline Tasmanaceae & 1 & \\
\hline Sum of marine elements & 4 & 8 \\
\hline
\end{tabular}

The ' + ' sign indicates that these have been found in addition to the counts

This result is corroborated by palynomorphs from the subrosion pipe. The simultaneous occurrence of Cerebropollenites pseudomassulae, Lunatisporites rhaeticus, Ovalipollis pseudoalatus, Rhaetipollis germanicus, and Riccisporites tuberculatus points to an assemblage that is Rhaetian in age. In more detail, an early to middle, probably middle Rhaetian age, is likely because of the presence of 


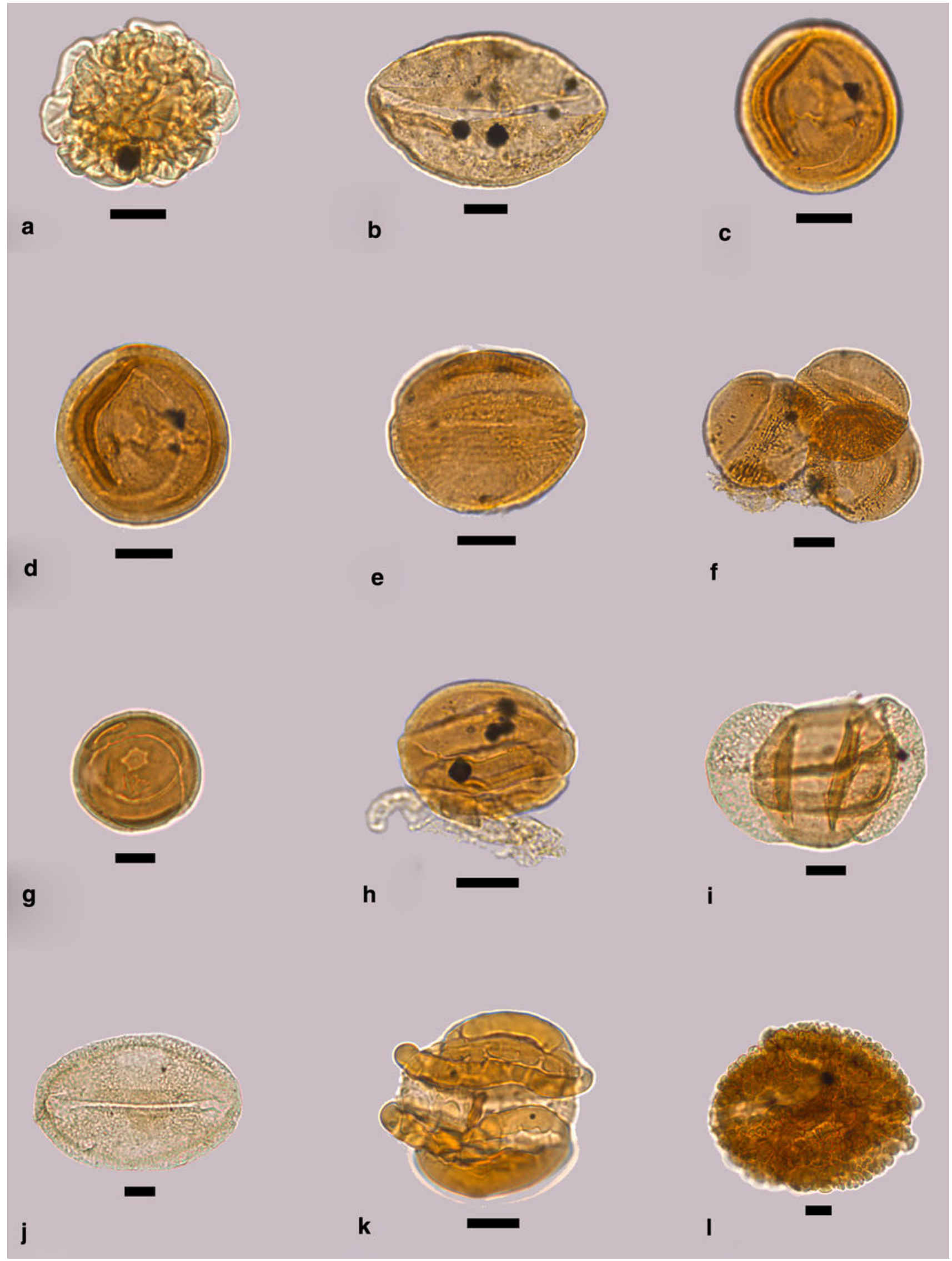


4 Fig. 6 A representative set of Dutch Rhaetian palynomorphs from the Rhaetian sediments of the subrosion pipe. a Cerebropollenites pseudomassulae. b Chasmatosporites magnolioides. c Circulina meyeriana, distal rimula. d Circulina meyeriana, polar view. e Classopollis. f 3/4 of tetrad of Classopollis. g Corollina zwolinskae. h Corollina zwolinskae, equatorial view showing both rimulae. i Lunatisporites rhaetianus. j Ovalipollis pseudoalatus. k Rhaetipollis germanicus, equatorial view. I tetrad of Ricciisporites tuberculatus. The scale bar equals $10 \mu \mathrm{m}$

Table 3 The Rhaetian bivalves found at Quarry IV

\begin{tabular}{lcc}
\hline & Total number & Percentage \\
\hline Tutcheria cloacina & 263 & 38.2 \\
Rhaetavicula contorta & 190 & 27.6 \\
Isocyprina sp. & 145 & 21.0 \\
Indet. & 39 & 5.7 \\
Lyriomyophoria postera & 27 & 3.9 \\
Pteromya sp. & 24 & 3.5 \\
Modiolus hillanus & 1 & 0.1 \\
Total & 689 & 100.0 \\
\hline
\end{tabular}

Corollina zwolinskae, Granuloperculatipollis rudis, and rare Heliosporites altmarkensis, and the absence of Cornutisporites spp., Limbosporites lundbladii, Perinosporites thuringiacus, Semiretisporis spp., Triancoraesporites spp., and Zebrasporites spp., taxa which are rare in the middle Rhaetian but become fair or common in the upper Rhaetian.

\section{Local correlation}

To investigate if both Rhaetian outcrops at Winterswijk are of the same age, sediments of both quarries and their contents have been studied in detail. Since the Rhaetian sediments are only $270 \mathrm{~m}$ apart, it could be assumed that if the sediments are of exactly the same age, the fossil content and sediment would be similar. Figure 7 provides an overview of the litho- and biostratigraphy of the exposed part of the Rhaetian sediments at Quarry IV.

\section{Sedimentology}

The clastic sediments of the subrosion pipe are uniformly grey, usually relatively hard and break along the bedding plane in layers with a thickness of millimeters to centimeters. Remains of a pyrite layer were found, as already mentioned by Klompmaker and Van den Berkmortel (2007). The pyrite layer has a maximum thickness up to $1 \mathrm{~cm}$ and contains disarticulated fish remains.

The Rhaetian sediments of Quarry IV can be divided into three lithological units. The stratigraphic uppermost

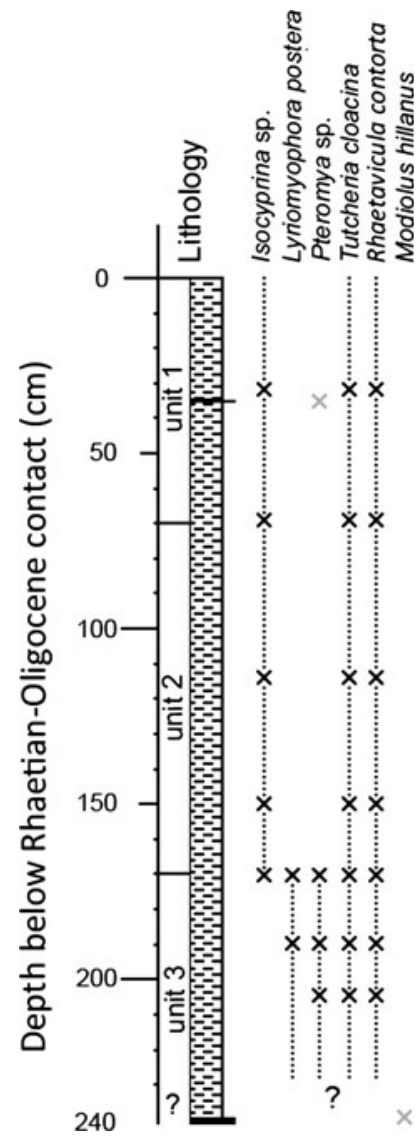

Fig. 7 Water level permitted only to study of the top $230 \mathrm{~cm}$ of the Rhaetian sediments at Quarry IV. The small, black layers in the stratigraphic column represent pyrite layers, while the dashed areas represent shale. The grey crosses indicate bivalve finds that are probably related to the pyrite layers

unit at $0-70 \mathrm{~cm}$ below the Rhaetian/Oligocene contact was grey to slightly blue, softer and prone to break down into thin layers of a millimeter or less. Also, a thin pyrite layer of $<1 \mathrm{~cm}$ in thickness was found $35 \mathrm{~cm}$ below the Rhaetian/ Oligocene contact (see Fig. 7). The shales were lighter in color, slightly brown, soft, and less prone to break into layers from 70 to $170 \mathrm{~cm}$ compared to the topmost $70 \mathrm{~cm}$. Sediments from 170 to $230 \mathrm{~cm}$ were similar in color to the topmost part, but less fissile, which is comparable to the Rhaetian shales from the subrosion pipe. Other, loose remains of a thicker pyrite layer containing bones were found shortly after the exposure of the Rhaetian sediments at Quarry IV in 2004, which probably originated from a depth of $240 \mathrm{~cm}$ below the sharp Rhaetian/Oligocene contact. This layer was found using a drill that was unable to penetrate a presumably several-centimeters-thick, pyritized layer. Remains of this layer contained disarticulated fish remains. It is unknown if this pyrite layer is the same as the one from the subrosion pipe. Thus, the sediments could not be used to correlate the two Rhaetian outcrops. 


\section{Bivalves}

Most Rhaetian bivalve species from Quarry IV were also present in the subrosion pipe. Moreover, the three most common bivalve taxa of the subrosion pipe are also the most common at Quarry IV. Detailed quantitative comparison is not considered to be useful here because percentages of species of the bivalve fauna do fluctuate throughout the lithology at Quarry IV (see Fig. 7). Isocyprina sp. was not present below $170 \mathrm{~cm}$ from the Rhaetian/Oligocene contact at Quarry IV. On the other hand, Tutcheria cloacina was more abundant below this level, while Pteromya sp. was present below $170 \mathrm{~cm}$. The three species were all found in the subrosion pipe. The shales of the subrosion could be best correlated to the shales at a depth around 170 below the Rhaetian/Oligocene contact at Quarry IV, although local variation in the presence of bivalves may have occurred.

\section{Palynology}

Sediments of Rhaetian age in the Netherlands are assigned to the Sleen Formation, the lowermost unit of the Altena Group (Van Adrichem-Boogaert and Kouwe 1993-1997). The upper part of this formation, which is of late Rhaetian age, shows invariably rich and well-preserved sporomorph assemblages (e.g., Herngreen and De Boer 1974). This is indicative of bottoms with a normal oxygen content, as is demonstrated in the nearby wells 'Ratum 41F-129' (Rijks Geologische Dienst/Geological Survey of the Netherlands Report 2297, 1995) and 'Sikkink 41E' (Rijks Geologische Dienst/Geological Survey of the Netherlands Report 2149, 1980), deep corehole 'Ratum' (Herngreen and De Boer 1974), the exposure at 'Landmark 94' (Herngreen and De Boer 1974) and in Quarry IV (Herngreen et al. 2005a, b). A conversion of the palynomacerals into structureless organic matter (SOM) as seen in both slides from the subrosion pipe is also well known from the Posidonia Shale Formation, Toarcian (the most important source rock of the Dutch oil), and the overlying lowermost Dogger sediments in the eastern Achterhoek (Herngreen et al. 2000b), from the Kimmeridge Clay Formation (Upper Kimmeridgian part), and in particular from the Clay Deep Member in the Central North Sea Graben (Herngreen et al. 2000a).

This massive occurrence of SOM is possibly related to the 'Early Jurassic' transgression, the first sedimentation cycle after the Triassic, which already starts in the Rhaetian. It is suggested that depressions originated by the Early Kimmerian tectonic phase were subsequently filled in with marginally marine Rhaetian sediments. They were possibly deposited in an isolated position such as temporary closed lagoons.
The remarkable difference in preservation (massive occurrence of SOM in shales of the subrosion pipe, but no SOM in Rhaetian shales of Quarry IV) and the far more frequently occurring Rhaetipollis germanicus and Riccisporites tuberculatus in Quarry IV compared to the subrosion pipe suggest that both Rhaetian sediments have not been deposited contemporaneously, although some minor local variations might have occurred (strong stratification, lagoonal settings). Moreover, transgression would have come from the north during the Early Kimmerian phase and, therefore, different palynomorph abundances would be expected.

Other constituents of the shales have been addressed as well. The Rhaetian sediments of the subrosion pipe contained thin layers rich in coprolites and thin, non-pyritized layers with disarticulated fish remains (teeth, scales, and bones). These have not been found in the profile of Fig. 7 (Quarry IV). On the other hand, scales, teeth, bones, and coprolites have been found at Quarry IV, most likely originating from the thick pyrite layer $240 \mathrm{~cm}$ below the Rhaetian/Oligocene contact. Furthermore, small cubic pyrite crystals have been found in the subrosion pipe and in the lower part of the profile of Quarry IV. In conclusion, the question of whether the Rhaetian shales from the subrosion pipe and from Quarry IV are of the same age cannot be answered.

\section{Correlation to NW-European Rhaetian sediments}

\section{Great Britain}

\section{Sedimentology}

Part of the British Rhaetian is the Penarth Group comprising (from old to young) the Westbury and Lilstock Formation, the latter including the Cotham and Langport Member (Warrington et al. 1980). The Penarth Group is primarily exposed in an elongated region across Great Britain starting near Bristol and further continuing in a NNE direction (Swift and Martill 1999: Fig. 1). The present geographic distance to Winterswijk is about $600 \mathrm{~km}$. The Westbury Formation, 4-10 m thick, and the Cotham Member, rarely exceeding a thickness of $8 \mathrm{~m}$, are composed of shales that are roughly comparable to the shales of the subrosion pipe and Quarry IV in that both shales are composed of dark non-calcareous, clastic strata. The calcareous mudstone sediments of the Cotham Member are, however, slightly coarser grained and lighter in color compared to the shales at Winterswijk. The $0-8 \mathrm{~m}$ thick Langport Member consists of light-colored micrites and calcareous shales (Swift 1999a), which is different from to the shales at Winterswijk. 
The Dutch Rhaetian shales are, thus, best comparable to the shales from the Westbury Formation.

\section{Bone beds}

Bone beds are especially prominent in the lower part and base of the Westbury Formation. These bone beds are variable in size and content, but some can be followed over $400 \mathrm{~km}$ in Great Britain according to Martill (1999). Several thin bone beds, including possible parts of a pyrite layer containing bones, were found in the subrosion pipe. The pyrite layer of the subrosion pipe contained bones, scales, coprolites, and teeth. Quarry IV yielded one, several-centimeters-thick, pyritized bone bed at $240 \mathrm{~cm}$ stratigraphically below the Rhaetian/Oligocene contact (Fig. 7). Vertebrate remains have yet to be found from the small pyrite layer $35 \mathrm{~cm}$ stratigraphically below the Rhaetian/Oligocene contact. Large vertebrate remains, which are scarce in the bone beds of the subrosion pipe (the largest bone has a length of about $3.0 \mathrm{~cm}$ ), have not been found in higher strata of the Westbury Formation (Martill 1999). The pyrite layer of Quarry IV at $240 \mathrm{~cm}$ stratigraphically below the Rhaetian/Oligocene contact, however, did yield larger vertebrate remains. Sykes (1977) noted that the Rhaetian shales of Great Britain contained bones within accumulations of sand and silt. These also have been found in the Rhaetian sediments of the subrosion pipe, but not at Quarry IV so far. The presence of bone beds, however, might indicate that the Rhaetian shales could be correlated to the lower part of the Westbury Formation.

\section{Bivalves}

The bivalve fauna resembles the British fauna closely, because all species found in the subrosion pipe and in the Rhaetian sediments of Quarry IV were also found in Great Britain (Table 4). Moreover, the common Rhaetian bivalve genera from Britain Chlamys, Isocyprina, Lyriomyophoria, Protocardia, Rhaetavicula, and Tutcheria (Ivimey-Cook et al. 1999) are often common at Winterswijk, with the exception of Chlamys sp. The latter taxon is mostly found in calcareous mudstones and in argillaceous limestones in Great Britain (Ivimey-Cook et al. 1999), a type of sediment that is absent at Winterswijk. The Rhaetian sediments of the subrosion pipe could be correlated to the entire Westbury Formation and the basal part of the Cotham Member based on bivalve ranges provided by Ivimey-Cook et al. (1999) and Wignall and Bond (2008). Three genera dominate the bedding planes, similar to parts of the British Westbury Formation (see Ivimey-Cook et al. 1999). The absence of the species Liostrea bristovi, 'Gervillia' ornata, Isocyprina depressum, Isocyprina germani, and Mytilus
Table 4 The presence/absence of the bivalve taxa found in the Netherlands, Great Britain, and Austria

\begin{tabular}{llll}
\hline & The Netherlands & Great Britain & Austria \\
\hline Isocyprina sp. & $\mathrm{X}$ & $\mathrm{X}$ & $\mathrm{X}$ \\
cf. Isocyprina sp. & $\mathrm{X}$ & & \\
Lyriomyophoria postera & $\mathrm{X}$ & $\mathrm{X}$ & \\
Modiolus hillanus & $\mathrm{X}$ & $\mathrm{X}$ & \\
Modiolus sp. & $\mathrm{X}$ & $\mathrm{X}$ & $\mathrm{X}$ \\
Protocardia rhaetica & $\mathrm{X}$ & $\mathrm{X}$ & $\mathrm{X}$ \\
Pteromya sp. & $\mathrm{X}$ & $\mathrm{X}$ & \\
Rhaetavicula contorta & $\mathrm{X}$ & $\mathrm{X}$ & $\mathrm{X}$ \\
Tutcheria cloacina & $\mathrm{X}$ & $\mathrm{X}$ & \\
\hline
\end{tabular}

cloacinus at Winterswijk suggests a correlation to the upper part of the Westbury Formation. The Rhaetian shales from Quarry IV might be correlated to the upper Westbury Formation or basal Cotham Member based on the presence of a specimen of Modiolus hillanus from Quarry IV. In addition, the low bivalve diversity at Winterswijk suggests correlation to the upper Westbury Formation.

\section{Palynology}

Quantitative sporomorph data, in particular those of predominant taxa, are, in the present authors' opinion, not suitable for longer-distance correlation as these predominances indicate specific environmental conditions. An example was recently mentioned by Bonis et al. (2008), who compared St. Audrie's Bay (Somerset, England) data with Hochalpgraben (Austria). In both sections, the sporomorph associations below the first negative carbon isotope record showed a dominance of pollen, mainly Classopollis, and just after the initial shift a distinct increase of spores and a decrease of Classopollis. In Austria, however, the dominance of spores persists, while in St. Audrie's Bay it is followed by a monotonous assemblage of Classopollis.

The samples under investigation should be compared with those from the Westbury Formation based on the absence and presence of palynomorphs. Very recently, an update of the St. Audries Bay palynology, concerning mainly sporomorph evidence, was published (Warrington et al. 2008). Unfortunately, there is a major sampling gap which prevents detailed comparison of the sporomorphs from the subrosion pipe with those from the Westbury Formation. Warrington et al. (2008) in their compilation of first and last occurrences of selected palynomorphs indicated only two species for the Westbury Formation: (1) Granuloperculatipollis rudis with its top in level $0.31 \mathrm{~m}$ above the base of the formation and (2) Kraeuselisporites reissingeri at level $1.07 \mathrm{~m}$ above base. It should be mentioned that the 
latter species is very rare in the Westbury Formation, which is comparable to elsewhere in the Rhaetian of NW Europe. In conclusion, this species does not seem appropriate for detailed correlation. The first species, however, indicates that at least an equivalent of the lower part of the Westbury Formation is present in the subrosion pipe in the eastern Netherlands. However, as outlined above, the sampling gap in the St. Audrie's Bay section does not allow correlation to higher levels of the Westbury Formation. Thus, correlation to the middle or upper part of the Westbury Formation cannot be excluded.

\section{Austria and Germany}

\section{Bivalves}

Several Rhaetian bivalves found in Austria (Tanner et al. 2004) were also found in the shales at Winterswijk (Table 4). The bivalve species Tutcheria cloacina, abundant at Winterswijk, was, however, absent in Austria. The notion that Austria and Winterswijk have fewer bivalve species in common as compared to Great Britain and Winterswijk has probably to do with the fact that the deposits in Great Britain and Winterswijk were formed in the same basin, the Anglo-Dutch Basin (Feist-Burkhardt et al. 2008: Fig. 13.25), in the Rhaetian, while the Austrian strata were formed in the small Eiberg Basin (Bonis et al. 2010), south of the Bohemian Massif, closer to the western part of the Tethys.

The upper part of the Upper Triassic, which is represented by the Kössen Formation in Austria, is thought to be equivalent in time to the British Westbury Formation (Golebiowski 1990). The Kössen Formation (about $600 \mathrm{~km}$ from Winterswijk) comprises the Hochalm and Eiberg Member (Golebiowski 1990; Tomašových 2006). The presumed Norian/Rhaetian boundary can be found within the upper part of the Hochalm Member (Golebiowski 1990), although Bonis et al. (2010: Fig. 1b) showed that the entire Hochalm Member would be Rhaetian in age. The end of the Rhaetian is thought to be equivalent to the end of the Choristoceras marshi ammonite zone, a zone comprising most of the Eiberg Member (Golebiowski 1990; Tanner et al. 2004; Tomašových 2006). The bivalves Protocardia rhaetica and Rhaetavicula contorta are found in the Rhabdoceras suessi ammonite zone which is stratigraphically below the Choristoceras marshi zone based on the bivalve ranges provided by Tanner et al. (2004: Fig. 3). This suggests that the Rhaetian deposits from the Winterswijk quarry complex cannot be correlated to the topmost Rhaetian of Austria. Instead, a middle Rhaetian age is favored because the Rhabdoceras suessi is not considered to be equivalent to the uppermost Rhaetian.
Palynology

Within the framework of the search for, and defining the Global Stratotype Section and Point (GSSP) for the base Jurassic System (Triassic/Jurassic boundary), and the Lower Jurassic Series and Hettangian Stage, Kürschner and his collaborators at the LPP (Utrecht University) paid much attention to various exposures in Austria and adjacent South Germany (Bonis et al. 2006; Kürschner et al. 2007). Moreover, Von Hillebrandt et al. (2007) presented a compilation of data dealing with the candidate-GSSP Kuhjoch section, Karwendel Mountains, Austria. Important conclusions based on the palynomorphs are: (1) The typical Rhaetian marker Rhaetipollis germanicus has its last occurrence about $5 \mathrm{~m}$ below the proposed T/J-boundary, (2) the last occurrence of Ovalipollis pseudoalatus is $\sim 3.5 \mathrm{~m}$ below it and (3) these studies are apparently dealing with a somewhat younger part of the Rhaetian than found in the Dutch Achterhoek area.

An up-to-date, detailed study of the German 'Rhaetian' (strata younger than the Norian Steinmergelkeuper and older than Lias $\alpha$ ) is not available. Nevertheless, the palynostratigraphic investigation of Schulz (1967), mainly dealing with wells and some exposures, is still significant, although it is restricted to the so-called Mittelr(h)ät to Toarcian, and some Steinmergelkeuper. Additional information on this is available from Achilles (1981) and Brenner (1986). A major conclusion is that several species as mentioned above appear spasmodic in the Mittelr(h)ät and become frequent in the Oberr(h)ät.

\section{Summary}

In conclusion, correlation to Great Britain, Austria, and Germany suggests that only a part of the Rhaetian is present at Winterswijk. Bivalve and palynological results suggest that the Dutch Rhaetian sediments most likely were deposited during the middle Rhaetian. This is in line with the notion in Feist-Burkhardt et al. (2008: p. 781) that the most pronounced transgression occurred in the middle Rhaetian indicated by a marine fauna.

\section{Paleoenvironment and paleoecology}

The Rhaetian in Europe is characterized by an extinction of the marine benthos that contributed to the Triassic/Jurassic extinction event (Kiessling et al. 2007). The most severe extinction was found at the top of the British Westbury Formation, where 15 out of 26 species went extinct. Twelve out of 26 infaunal species from the Westbury Formation failed to survive into the Jurassic (Wignall and Bond 2008). At generic level, extinction rates were higher in southern 
Europe (Hallam 2002; Wignall and Bond 2008). Even prior to this dramatic extinction event, environments may have been already stressed. This is suggested by the low number of bivalve species at Winterswijk (eight in total). Bambach (1977) pointed out that on average 7-8 marine invertebrates species existed in stressed Mesozoic environments.

Not only the bivalves suggest a stressed regime. Crinoid remains are absent from Dutch Rhaetian sediments, indicating shallow conditions or low oxygen levels near the bottom (Swift 1999b). Also, the palynodebris of the subrosion pipe is indicative of dysaerobic bottom conditions based on the conversion to SOM. The upper part of the bottom profile and bottom waters were most likely not anoxic because of the high number of bivalves and the presence of tiny burrows. The bivalve Rhaetavicula contorta is suggested to have been epifaunal, while Isocyprina, Lyriomyophoria postera, and Protocardia rhaetica might have been shallow infaunal burrowers (Ivimey-Cook et al. 1999). The relatively high number of articulated valves of Tutcheria cloacina suggest that it was an infaunal burrower because articulated shells are more likely to be preserved if a bivalve lives infaunally. Hence, at least some oxygen was probably present in the bottom.

Other marine organisms do suggest a stressed environment caused by changing or low salinity levels. In contrast to southern Europe, no cephalopods have been found in the Dutch Rhaetian bone beds and shales, and in the British Rhaetian bone beds (Martill 1999). Corals, sponges, bryozoans, and brachiopods are also absent from the Dutch Rhaetian shales, as well as echinoderms, except for a small population of brittle stars (Thuy et al. 2008). Echinoderms have been found in the British Westbury Formation, but only in low numbers. On the other hand, instead of changes in the salinity, muddy bottom waters might have hampered the existence of these organisms. The filter-feeding bivalves, however, are numerous and survived. The absence of the other groups of animals mentioned above, which are predominantly marine and cannot withstand changing salinity levels, strongly suggests that salinity levels might have fluctuated. A similar hypothesis was postulated by Schmitz et al. (1991), who studied ${ }^{87} \mathrm{~S} /{ }^{86} \mathrm{~S}$ ratios found in phosphates of the fish Saurichthys acuminatus from the bone beds of the Westbury Formation. Their results showed significant differences compared to the expected ratios for the Rhaetian seawaters. They suggested that the bone beds might be either reworked or freshwater deposits. Hallam and El Shaarawy (1982) also suggested that the salinity crisis in the Alpine region might have been present in northwestern Europe as well during the Rhaetian.

The predominant palynological associations of this study are indicative of a near-coastal environment with definite marine influences. The low percentage $(<5 \%)$ of the marine elements (mainly the dinoflagellate Rhaetogonyaulax) corroborates this interpretation. The marine fauna and flora of the British Westbury Formation lived in a shallow, storm-dominated marine shelf (Macquaker 1999). Judgments about water depth remain uncertain, as SOM may occur in very different sedimentary settings such as a stratified, even shallow, water column and below wave base. Feist-Burkhardt et al. (2008: p. 781) suggested that the large marine transgression during the middle Rhaetian commenced in the west near Great Britain. Thus, the sediments might have been deposited in a shallower environment in the eastern part of the basin, which might explain the slightly different interpretations for the paleoenvironments of the Rhaetian shales of Great Britain and Winterswijk.

\section{Subrosion pipe}

\section{Stratigraphy}

The subrosion pipe comprised (based on Herngreen 1989; Klompmaker and Van den Berkmortel 2007; Lissenberg 1989; Oosterink et al. 2005, 2006 and results herein):

1) Middle Triassic (Anisian, Bithynian) or Muschelkalk, $\sim 240 \mathrm{Ma}, 9 \mathrm{~m}$ from the bottom of the quarry floor

2) Upper Triassic (middle Rhaetian), $\sim 202 \mathrm{Ma}, 2-4 \mathrm{~m}$

3) Lower Jurassic (middle to late Hettangian), $\sim 198 \mathrm{Ma}$, mixed into the Rhaetian shales

Quarry IV has a slightly different profile (based on Herngreen et al. 2005a, b and results herein):

1) Middle Triassic (Anisian, Bithynian), $240 \mathrm{Ma}$, tens of meters from the quarry floor

2) Upper Triassic (Norian-Rhaetian), $\sim 204 \mathrm{Ma}, 7 \mathrm{~cm}$ (see Fig. 8)

3) Upper Triassic (middle Rhaetian), $\sim 202 \mathrm{Ma}, \sim 4 \mathrm{~m}$

4) Paleogene (lower Oligocene), $\sim 30 \mathrm{Ma}, 3 \mathrm{~m}$ directly above the Rhaetian shales

5) Glacial till of about $2.5 \mathrm{~m}$

6) Fertile soil of about $60 \mathrm{~cm}$

Unfortunately, the upper 5-7 $\mathrm{m}$ of the subrosion pipe was lost due to excavation (Oosterink et al. 2005, 2006). Nonetheless, the thicknesses of Rhaetian and Hettangian sediments can be estimated. Borehole 'Ratum', less than three $\mathrm{km}$ to the northeast of the quarry, yielded Rhaetian sediments with a thickness of $10.9 \mathrm{~m}$ based on, for example, the presence of Rhaetavicula contorta (Gerth 1955; Herngreen and De Boer 1974), while borehole 'J', even closer to the quarry, yielded $5 \mathrm{~m}$ of Rhaetian sediments based on palynomorphs (Herngreen and De Boer 1974). The latter was, however, the lowermost part of the borehole, suggesting that the total thickness was more than $5 \mathrm{~m}$. Herngreen et al. 


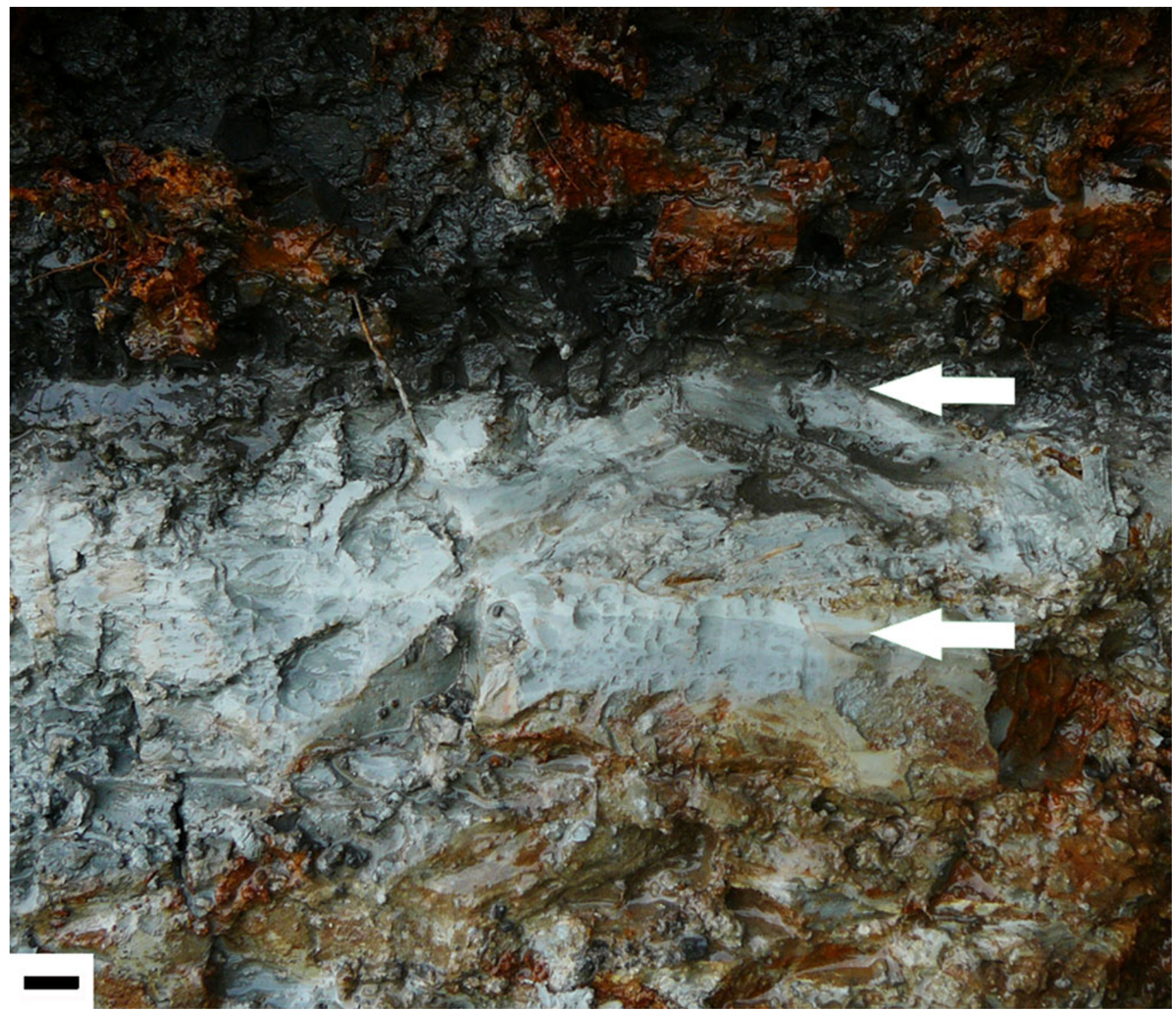

Fig. 8 The stratigraphic succession at Quarry IV. The lowermost layers are Anisian in age, in the middle the light-grey Norian-Rhaetian sediments (Herngreen et al. 2005b) $(7 \mathrm{~cm})$, the topmost layers are
Rhaetian shales. Note the small difference in color between the Anisian and the Norian-Rhaetian sediments. Arrows indicate transitions

by Hettangian ammonites that were found intermixed with the lowermost part of the Rhaetian shales in the subrosion pipe (Klompmaker and Van den Berkmortel 2007). They hypothesized that meters of Hettangian sediments might have been present in the subrosion pipe before excavation based on the thicknesses of Hettangian sediments found in cores from boreholes in the close proximity. Unfortunately, it cannot be determined if Hettangian sediments were topped by younger strata.

\section{Age of formation}

Oosterink et al. $(2005,2006)$ stated that the subrosion pipe could not have formed after the Quaternary because of the 
absence of a depression before the excavation of Quarry III. Ice ages would have leveled the sink hole by means of sediment displacement and cryoturbation. The authors suggested that the collapse took place after the tilting of the Anisian strata, which dip $\sim 10^{\circ}$ north. This is because the strata at the southern edge of the pipe were dragged down, while the strata at the northern edge were not. Furthermore, Oosterink et al. (2006) suggested that the pipe collapsed well after the Oligocene because Oligocene sediments in the neighborhood of the quarry are tilted, while Quaternary strata are not. This is based on the observation that the pipe would be vertical (Th. Simon, pers. comm., 2008). Further, Simon (pers. comm., 2008) mentioned that leaching requires low mineralized groundwater and is relatively fast on geological time scales. Therefore, the Röt in the subsurface of the Winterswijk quarry might have leached after any marine deposits because at that time low mineralized groundwater might be present because of terrestrial conditions. Hence, this water could have dissolved the Röt gypsum/anhydrites faster than seawater. This is because freshwater can dissolve more minerals generally. Moreover, while groundwater flow in marine settings is slow far away from the coast, groundwaters in near-coastal and terrestrial settings might dissolve the Röt evaporite because they might flow faster (Th. Simon, pers. comm., 2008).

The latter suggestion, however, implies that marine conditions prevailed from the end of the main tilting of the strata (Late Cretaceous) past the time that the Oligocene sediments were deposited at Quarry IV. The Winterswijk area was, however, above sea level prior to the early Oligocene (M. van den Bosch, pers. comm., 2008) due to the Pyrenic phase. In addition, Oosterink (1986) suggested that the Winterswijk area might be continental during Late Cretaceous times. It, thus, appears that last argument provided by Oosterink et al. (2006) as mentioned above can be considered to be ambiguous.

The argument that involves the dip of the Oligocene and Quaternary strata, and the vertical position of subrosion pipe, can be challenged as well. The dip of Oligocene strata is lower than the dip of the Anisian and Rhaetian strata at Quarry IV (M. van den Bosch, pers. comm., 2008). The Anisian layers have a dip of $9-16^{\circ} \mathrm{N}$, while the Rhaetian shales at Quarry IV dip $20.7^{\circ} \mathrm{N}$ on average as based on 18 measurements. The Oligocene strata were discordantly deposited on the Rhaetian strata and the dip is likely from 0-9 ${ }^{\circ}$. Indeed, Van den Bosch and Brouwer (2009: Fig. 4) showed that the dip of the Oligocene is significantly lower than the Anisian and Rhaetian strata north of the quarry. A dip of a couple of degrees is not likely to be observed from the edges of the subrosion pipe. This is corroborated a figure of the subrosion pipe (Oosterink et al. 2006: Fig. 2) which shows no clear vertical edge. Moreover, the distinct Anisian/Rhaetian contact does dip towards the north
(Oosterink et al. 2006: Fig. 2), which suggests that the subrosion pipe could be slightly tilted. The collapse into the pipe, however, might have caused the northward dip. On the other hand, on the whole southern part, the contact appears to be tilted to the north, while the northern part is horizontal. The tilting hypothesis might, therefore, be considered more likely. This strengthens the hypothesis that the subrosion pipe was formed prior to the Oligocene.

The Hettangian ammonites from the subrosion pipe (Klompmaker and Van den Berkmortel 2007) provide strong evidence against the formation of the subrosion pipe after the deposition of Oligocene sediments at Quarry IV. The Hettangian sediments certainly would have been removed by the erosional phase that removed the sediments on top of the Rhaetian at Quarry IV if the subrosion pipe formed after the deposition of the Oligocene. This is, however, not the case. Moreover, Hettangian sediments would be expected to be found more likely at Quarry IV than in the more southerly located subrosion pipe because of the generally north-dipping strata at the Winterswijk quarry complex. So, it is likely that the subrosion pipe formed prior instead of after the deposition of the Oligocene strata.

Another clue comes from dips in Eocene strata. Van den Bosch (1999) noted that the marine sediments of the Dongen Formation (Eocene), exhibiting a dip of $\sim 10^{\circ}$, were disconcordantly overlain by younger, horizontally lying Eocene marine sediments, also from the Dongen Formation. The dip of $\sim 10^{\circ}$ strongly suggests that the subrosion pipe formed after the deposition of this part of the Dongen Formation. The Winterswijk area might have been above sea level in the Late Eocene because of the presence of this unconformity. Maarten van den Bosch (pers. comm., 2008) confirmed that the Winterswijk area was above sea level prior to the Early Oligocene. As a result, leaching could have taken place in middle part of the Eocene and, subsequently, caused the collapse of strata, thereby forming the subrosion pipe.

Acknowledgments We kindly thank the 'Working Group Muschelkalk' and the exploiting 'Ankerpoort Company' for permission to access and study the Rhaetian sediments at Quarry IV of the Winterswijk quarry complex. Constructive comments by Theo Simon and an anonymous person on an earlier draft helped to improve the manuscript. Dirk Munsterman and Roel Verreussel (both TNO Built Environment and Geosciences/Geological Survey of the Netherlands) are thanked for access to the photo equipment. We are grateful to Cristina Robins (Kent State University) for linguistic improvements. Maarten van den Bosch provided useful information. Tony Hallam (University of Birmingham) is thanked for helping with some taxonomic issues on bivalves. For various reasons, the following are thanked: Betsie Klompmaker, Edo Klompmaker, Lucy van der Heiden-Klompmaker, and Nationaal Natuurhistorisch Museum Naturalis (Leiden). The reviewer Elias Samankassou (University of Fribourg/Free University of Amsterdam) and the managing editor André Freiwald improved the manuscript substantially with their helpful comments. 
Open Access This article is distributed under the terms of the Creative Commons Attribution Noncommercial License which permits any noncommercial use, distribution, and reproduction in any medium, provided the original author(s) and source are credited.

\section{References}

Achilles H (1981) Die rätische und liassische Mikroflora Frankens. Paläontograph Abt B 179:1-86

Bambach RK (1977) Species richness in marine benthic habitats through the Phanerozoic. Paleobiol 3:152-167

Bonis NR, Ruhl M, Kürschner WM (2006) Carbon-isotope stratigraphy and palynostratigraphy of a Triassic-Jurassic boundary section in the Central European Basin (Kammerbruch, Germany): preliminary results. NSG-day 2006, Utrecht, The Netherlands

Bonis NR, Kürschner WM, Krystyn L (2008) Palynological criteria to define the base of the Jurassic. Geophys Res Abstr 10: EGU2008A-02098

Bonis NR, Ruhl M, Kürschner WM (2010) Climate change driven black shale deposition during the end-Triassic in the western Tethys. Palaeogeog Palaeoclim Palaeoecol 290:151-159

Brenner W (1986) Bemerkungen zur Palynostratigraphie der RhätLias-Grenze in SW-Deutschland. Neues Jahrb Geol Paläont, Abh 173:131-166

Feist-Burkhardt S, Götz AE, Szulc J, Borkhataria R, Geluk M, Haas J, Hornung J, Jordan P, Kempf O, Michalik J, Nawrocki J, Reinhardt L, Ricken W, Röhling H-G, Rüffer T, Török A, Zühlke R (2008) Triassic. In: McCann T (ed) The geology of Central Europe. Geol Soc Lond, pp 749-821

Gerth H (1955) Die Fossilführung des Jura in den Bohrungen der 'Rijksopsporing van Delfstoffen' bei Winterswijk und ihre stratigraphische Bedeutung. Med Geol Stichting, Nieuwe Serie 9:45-54

Golebiowski R (1990) The Alpine Kössen Formation, a key for European topmost Triassic correlations. A sequence- and ecostratigraphic contribution to the Norian-Rhaetian discussion. Albertiana 8:25-35

Hallam A (2002) How catastrophic was the end-Triassic mass extinction? Lethaia 35:147-157

Hallam A, El Shaarawy Z (1982) Salinity reduction of the end-Triassic sea from the Alpine region into northwestern Europe. Lethaia 15:169-178

Herngreen GFW (1989) Resultaat van het palynologisch onderzoek van een kleimonster uit Steengroeve III te Winterswijk. Rijks Geologische Dienst-Geological Survey of the Netherlands, Paleontologie Mesozoicum, (Palynologie), Report 2217:1-2

Herngreen GFW, De Boer KF (1974) Palynology of Rhaetian, Liassic and Dogger strata in the eastern Netherlands. Geol Mijnb 53:343368

Herngreen GFW, Wong ThE (2008) (Jurassic in) The Netherlands. In: McCann T (ed) The geology of Central Europe, Vol. 2, Mesozoic and Cenozoic; Chap. 14, Jurassic (Pienkowski G, Schudack ME, coordinators). Geol Soc Lond, pp 836-842

Herngreen GFW, Wong ThE (2007) Cretaceous. In: Wong ThE, Batjes DAJ, De Jager J (eds) Geology of the Netherlands. Royal Netherlands Academy of Arts and Sciences, Amsterdam, pp 127-150

Herngreen GFW, Kerstholt SJ, Munsterman DK (2000a) CallovianRyazanian ("Upper Jurassic") palynostratigraphy of the Central North Sea Graben and Vlieland Basin, the Netherlands. Med Ned Inst Toegep Geowet TNO 63:1-99

Herngreen GFW, Van den Bosch M, Lissenberg T (2000b) Nieuwe inzichten in de stratigrafische ontwikkeling van Jura, Krijt en Onder-Tertiair in de Achterhoek. Grondb Hamer 54:70-92

Herngreen GFW, Van Konijnenburg-van Cittert JHA, Oosterink HW (2005a) New geological data (Middle Triassic, Rhaetian-Liassic and Oligocene) of the Winterswijk quarry, the eastern Netherlands. Neth J Geosc 84:409-413

Herngreen GFW, Van Konijnenburg-van Cittert JHA, Oosterink HW, Van der Ham RWJM (2005b) Nieuwe geologische, palynologische en paleobotanische gegevens (Muschelkalk, Rhaetien-Lias en Oligoceen) uit de steengroeven van Winterswijk. Grondb Hamer 59:84-97

Ivimey-Cook HC, Hodges P, Swift A, Radley JD (1999) Bivalves. In: Swift A, Martill DM (eds) Fossils of the Rhaetian Penarth Group. Palaeontol Assoc, Lond, pp 83-127

Janssen N, Dammers G (2008) Sample processing for pre-Quaternary palynology. Internal report TNO Built Environment and Geosciences-Geological Survey of the Netherlands

Kiessling W, Aberhan M, Brenneis B, Wagner PJ (2007) Extinction trajectories of benthic organisms across the Triassic-Jurassic boundary. Palaeogeog Palaeoclim Palaeoecol 244:201-222

Klompmaker AA, Van den Berkmortel BJHM (2007) Earliest Jurassic (Hettangian) psiloceratoid ammonites from a subrosion pipe in Winterswijk, the eastern Netherlands. Neth J Geosc 86:379-388

Kürschner WM, Bonis NR, Krystyn L (2007) Carbon-isotope stratigraphy and palynostratigraphy of the Triassic-Jurassic transition in the Tiefengraben section-Northern Calcareous Alps (Austria). Palaeogeog Palaeoclim Palaeoecol 244:257280

Lissenberg T (1989) Mikropaleontologisch onderzoek aan een kleimonster uit de steengroeve te Winterswijk. Rijks Geologische Dienst-Geological Survey of the Netherlands, Paleontologie Mesozoicum (Foraminiferen en Ostracoden), Report 497:1-5

Macquaker JHS (1999) Aspects of the sedimentology of the Westbury Formation. In: Swift A, Martill DM (eds) Fossils of the Rhaetian Penarth Group. Palaeontol Assoc, Lond, pp 39-48

Martill DM (1999) Bone beds of the Westbury Formation. In: Swift A, Martill DM (eds) Fossils of the Rhaetian Penarth Group. The Palaeontological Association, London, pp 49-64

Moore C (1861) On the zones of the Lower Lias and the Avicula contorta Zone. Quart J Geol Soc Lond 23:483-516

NITG-TNO (1998) Geological atlas of the subsurface of the Netherlands (1:250 000). Explanation to Map sheet X AlmeloWinterswijk. Netherlands Institute of Applied GeosciencesTNO (Haarlem)

Oosterink HW (1986) Winterswijk, Geologie Deel II. De Trias-periode (geologie, mineralen en fossielen). Wet Med Konink Ned Natuurhist Ver 178:1-120

Oosterink HW, Simon Th, Winkelhorst H (2005) Een subrosieverschijnsel in de Muschelkalkgroeve van Winterswijk. Grondb Hamer 59:78-83

Oosterink HW, Simon Th, Hagdorn H, Winkelhorst H (2006) A subrosion pipe fill in the Lower Muschelkalk, Winterswijk Quarry, Eastern Netherlands. Neth J Geosc 85:293-297

Rijks Geologische Dienst/Geological Survey of the Netherlands (1980) Resultaten van het palynologisch onderzoek van boring Sikkink, nabij Bredevoort. Palynologie Mesozoicum, Report 2149 (11-03-1980)

Rijks Geologische Dienst/Geological Survey of the Netherlands, 1995. Palynologisch onderzoek van boring Ratum 41F-129, 11.20176.90 m. Palynologie Mesozoicum, Report 2297 (31-01-1995)

Schmitz B, Aberg G, Werdelin L, Forey P, Bendix-Almgreen SE (1991) ${ }^{87} \mathrm{~S} /{ }^{86} \mathrm{~S}, \mathrm{Na}, \mathrm{F}, \mathrm{Sr}$ and La in skeletal fish debris as a measure of palaeosalinity of fossil fish habitats. Geol Soc Am Bull 103:786-794

Schulz E (1967) Sporenpaläontologische Untersuchungen rätoliassischer Schichten im Zentralteil des Germanischen Beckens. Paläont Abh B 2(3):541-633

Swift A (1999a) Stratigraphy (including biostratigraphy). In: Swift A, Martill DM (eds) Fossils of the Rhaetian Penarth Group. Palaeontol Assoc, Lond, pp 15-30 
Swift A (1999b) Echinoderms. In: Swift A, Martill DM (eds) Fossils of the Rhaetian Penarth Group. Palaeontol Assoc, Lond, pp 159 167

Swift A, Martill DM (1999) Introduction-The Penarth Group. In: Swift A, Martill DM (eds) Fossils of the Rhaetian Penarth Group. Palaeontol Assoc, Lond, pp 9-13

Sykes JH (1977) British Rhaetian bone beds. Merc Geol 6:197-239

Tanner LH, Lucas SG, Chapman MG (2004) Assessing the record and causes of Late Triassic extinctions. Earth-Sci Rev 65:103-139

Thuy B, Klompmaker AA, Jagt JWM (2008) Rhaetian ophiuroids from the Netherlands: a preliminary report. Fourth Workshop of German and Austrian Echinoderm Research, Vienna, Austria, 49-50

Tomašových A (2006) Linking taphonomy to community-level abundance: insights into compositional fidelity of the Upper Triassic shell concentrations (Eastern Alps). Palaeogeog Palaeoclim Palaeoecol 235:355-381

Van Adrichem-Boogaert HA, Kouwe WFP (Compilers) (1993-1997) Stratigraphic nomenclature of the Netherlands, revision and update. Med RGD 50

Van den Bosch M (1999) Een analyse van bodembewegingen tijdens het Tertiair ten noorden van Winterswijk (provincie Gelderland, Nederland). Contr Tert Quat Geol 36:109-132

Van den Bosch M, Brouwer F (2009) Bodemkundige geologische inventarisatie van de gemeente Winterswijk. Alterra-rapport 1797, bijlagen
Von Hillebrandt A, Krystyn L, Kürschner WM (2007) A candidate GSSP for the base of the Jurassic in the Northern Calcareous Alps (Kuhjoch section, Karwendel Mountains, Tyrol, Austria). ISJS Newsl 34:2-20

Warrington G, Audley-Charles MG, Elliott RE, Evans WB, IvimeyCook HC, Kent PE, Robinson PL, Shotton FW, Taylor FM (1980) A correlation of Triassic rocks in the British Isles. Geol Soc London Spec Rep 13

Warrington G, Cope JCW, Ivimey-Cook HC (2008) The St. Audrie's Bay-Doniford Bay section, Somerset, England: updated proposal for a candidate Global Stratotype Section and Point for the base of the Hettangain Stage, and of the Jurassic System. Int Subcomm Jur Strat, Newsl 35:2-66

Whitaker MF (1984) The usage of palynostratigraphy and palynofacies in definition of Troll Field geology. Proceedings 6th Offshore Northern Seas Conference, Stavanger, Norway, Paper G6, 1-28

Wignall PB, Bond DPG (2008) The end Triassic and Early Jurassic mass extinction records in the British Isles. Proc Geol Assoc 119:73-84

Ziegler PA (1990) Geological Atlas of Western and Central Europe. Elsevier for Shell International Petroleum Maatschappij, 2nd edn. Geol Soc Publ House, Bath 